\title{
Nå kommer nye europeiske kostråd for diabetes
}

Høyt fiberinntak og balansert fett- og proteininntak gjelder fortsatt. Men de nye rådene legger mer vekt på at livsstilsendring og vektreduksjon kan gi en bedring av diabetes type 2.

\section{Anne-Marie Aas}

Klinisk ernæringsfysiolog

Medisinsk klinikk, Seksjon for klinisk ernæring, Avdeling for klinisk service, Oslo universitetssykehus

Diabetes

Ernæring

Sykepleien 2022;110(87860):e-87860

DOI: 10.4220/Sykepleiens.2022.87860

\section{Hovedbudskap}

The Diabetes and Nutrition Study Group (DNSG) (1) er en undergruppe av den europeiske sammenslutningen av forskere innen diabetes, European Association for the Study of Diabetes (EASD). Siden 1988 har DNSG gitt råd om kosthold ved behandling av diabetes. I 2004 kom forrige oppdatering, og nå 17 år senere er snart nye råd på plass. Kostrådene blir nok ikke radikalt forskjellige fra tidligere, men det som er nytt, er at vi har et mye bedre vitenskapelig fundament for å gi de rådene vi gir. 
De norske retningslinjene for kosthold ved diabetes fra 2019 samsvarer i stor grad med de europeiske. I skrivende stund er også de norske retningslinjene til revidering. I Norge er det mer snakk om en redaksjonell «slanking» av omfanget av retningslinjene: Helsedirektoratet $\varnothing$ nsker mer kortfattede og oversiktlige kostråd og færre detaljer om kunnskapsgrunnlaget som ligger bak rådene.

Jeg har vært aktivt med på å utarbeide både de europeiske anbefalingene, som snart er ferdige, og de norske retningslinjene for kosthold ved diabetes. Videre i artikkelen vil jeg sammenfatte noe av innholdet i disse anbefalingene og samtidig peke på de viktigste endringene fra tidligere retningslinjer.

\section{Vektreduksjon kan gi remisjon av diabetes type 2}

For å forebygge og behandle diabetes type 2 er kost- og treningstiltak som gir vektreduksjon, mest effektivt. Men hvilket kosthold har best virkning for å oppnå varig vektreduksjon ved diabetes type 2 ? Og hvilken vektreduksjonsstrategi er den beste for at personer med diabetes skal oppnå remisjon, altså en normalisering av blodsukkeret?

I høst kom endelig artikkelen som skal gi oss svaret på dette og danne grunnlaget for The Diabetes and Nutrition Study Groups (DNSG) anbefaling om vektreduksjon (2). Artikkelen inneholder to systematiske kunnskapsoppsummeringer (systematic review) med metaanalyser.

Først gjorde forfatterne en såkalt paraplygjennomgang (umbrella review): De foretok en systematisk kunnskapsoppsummering av alle publiserte kunnskapsoppsummeringer som inkluderte randomiserte, kontrollerte studier av vektreduksjon ved hjelp av kostendring.

De satte sammen funnene for alle disse studiene, sorterte dem etter kostholdstype og vurderte kvaliteten både på studiene som helhet og på hvor godt kunnskapsgrunnlaget var i hver enkelt publikasjon.

Deretter gjorde de en ny kunnskapsoppsummering av alle vektreduksjonsstudier som oppnådde vektreduksjon ved kostendring, og som rapporterte om graden av remisjon fra diabetes type 2. Remisjon ble her definert som å ha blodsukker under diagnosegrensen for diabetes ( $\mathrm{HbAlc}<48 \mathrm{mmol} / \mathrm{mol}$ ), uten bruk av medikamenter.

Konklusjonen var at vektreduksjonsopplegg som inkluderte lavkaloridietter (under $1000 \mathrm{kcal} / \mathrm{d}$ ) og måltidserstattere ga størst vekttap ved diabetes type 2 .

Måltidserstattere kan være shaker eller supper som er laget slik at de kan gi fullverdig næring, men minimalt med kalorier. 
Ingen bestemt sammensetning av kosten, som lavkarbo, høyprotein eller vegetarisk, ga større vekttap enn andre kostsammensetninger. Program som hadde en startfase der all mat ble byttet ut med kalorireduserte måltidserstattere, ga størst grad av remisjon av diabetes type 2 (2).

\section{Remisjon ved livsstilsendring gis mer oppmerksomhet}

Oppmerksomheten på at man kan oppnå remisjon ved hjelp av livsstilsendring og vektreduksjon, er ny både i de norske og europeiske anbefalingene. Mye av årsaken til den $\varnothing$ kte oppmerksomheten er nok Direct-studien fra 2018, hvor nesten halvparten i vektreduksjonsgruppen (46 prosent) fikk normalisert blodsukkeret sitt etter ett år uten hjelp av medisiner (3).

Jo mer de hadde gått ned i vekt, jo høyere var sannsynligheten for at de ble kvitt sin diabetes: Blant dem som hadde gått ned 15 kilo eller mer, var 86 prosent diabetesfrie etter ett år (3). Etter to år var fortsatt 36 prosent av dem som hadde deltatt i vektreduksjonsprogrammet, diabetesfrie sammenliknet med 3 prosent $i$ kontrollgruppen (4).

Muligheten til å bli diabetesfri som følge av vektreduksjon er nok ikke så godt kjent verken hos pasienter eller helsepersonell. Derfor legger vi vekt på dette i anbefalingene.

\section{Ekstrem lavkarbokost anbefales ikke}

En av kunnskapsoppsummeringene som inngikk i paraplygjennomgangen som er nevnt tidligere, var en kunnskapsoppsummering som vi gjorde for å se om lavkarbokost ga bedre effekt på metabolsk kontroll hos voksne med diabetes type 2, sammenliknet med et sunt kosthold med høyere karbohydratinnhold (5).

Konklusjonen fra denne analysen var at kost med både et relativt lavt og et høyt karbohydratinnhold hadde gunstig effekt på HbA1c, vekt, blodtrykk og blodlipider. Bortsett fra en noe gunstigere effekt på triglyseridnivået ved lavkarbokost var det ingen vesentlig forskjell i effekten av de to kosttypene.

Både i de norske og europeiske anbefalingene konkluderer vi derfor med at det går fint med en moderat lavkarbokost, som innebærer et karbohydratinntak ned mot 30 prosent av kaloriinntaket. Forutsetningen er at kostholdet må inneholde tilstrekkelig med fiber og ligge innenfor anbefalingene for mettet fett og proteiner.

Ekstrem lavkarbokost, som ketogen diett, anbefales ikke. Det skyldes usikkerhet rundt langtidseffekten av slik kost. Det er dessuten vanskelig å få dekket behovet for fiber, vitaminer og mineraler når man utelater det meste av karbohydratrike matvarer. 
Når vi ser på store befolkningsunders $\emptyset$ kelser og utvikling over tid, ser vi dessuten at både et ekstremt lavt og et ekstremt høyt inntak av karbohydrater kan være skadelig (6).

\section{Fiberrik kost forebygger hjerte- og karsykdom og for tidlig død}

DNSG har alltid fremmet viktigheten av et fiberrikt kosthold ved diabetes, men i de nye retningslinjene vil vi påpeke dette i enda større grad. I en ny systematisk kunnskapsoppsummering har vi vist at et høyt fiberinntak kan redusere både total og kardiovaskulær dødelighet blant personer med diabetes eller prediabetes (7).

Det er dessuten slik at jo mer fiber man spiser, jo bedre effekt har det på blodsukkerreguleringen (HbA1c, fastende blodsukker og insulinfølsomhet), blodlipider, kroppsvekt og inflammasjonsmarkøren CRP, der større doser, altså høyere fiberinntak, har gunstigere effekt (7).

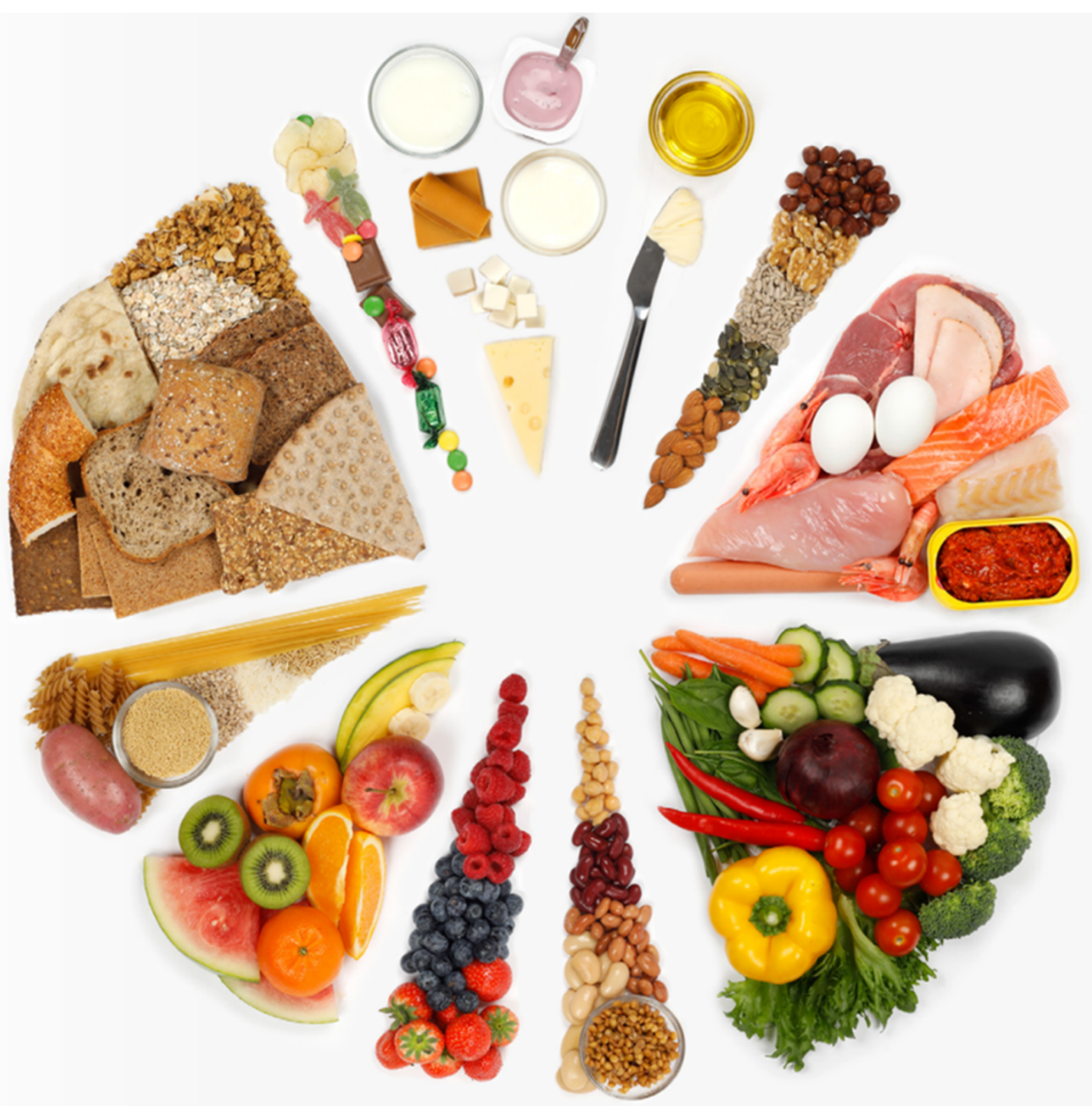

SPIS GODT: Sunt kosthold ved diabetes type 2. Foto: Kjersti Gjems / Helsedirektoratet 
Ideelt sett bør fiberinntaket være rundt $35 \mathrm{~g}$ per dag, men best effekt så man hos dem som gikk fra et lavt til et moderat eller høyt fiberinntak. Ifølge de ferskeste tallene fra Norge er gjennomsnittsinntaket her i landet på $28 \mathrm{~g}$ per dag (7). Selv om inntaket ikke er så lavt som i mange andre land, har vi fortsatt et forbedringspotensial.

Vi bør øke fiberinntaket ved å spise mer mat som har et naturlig høyt fiberinnhold, som fullkornsprodukter, grønnsaker, belgvekster, hel frukt, frø og nøtter. Om det er vanskelig å nå den anbefalte mengden fiber på 35 gram per dag, kan man også ta $\mathrm{i}$ bruk fibertilskudd eller matvarer som er tilsatt fiber.

I en forskningsstudie vi utførte på Oslo universitetssykehus blant personer med diabetes type 2, rapporterte deltakerne om et gjennomsnittlig fiberinntak på 32 gram per dag (9). Det viser at det ikke er umulig å komme opp i disse inntakene, selv uten tilskudd, hvis man er litt bevisst. Tabell 1 viser et forslag til en dagsmeny som gir $35 \mathrm{~g}$ fiber (10).

Tabell 1. Eksempel på en dagsmeny som gir 35 gram fiber

\begin{tabular}{|lll|}
\hline Måltid & Mat og drikke & Fibermengde i gram \\
Frokost & 1 porsjon havregrøt med melk & 5,6 \\
& 1 glass lettmelk & 0 \\
Lunsj & 2 skiver ekstra grovt brød & 6,6 \\
& med margarin, gulost og kokt skinke & 0 \\
& 3 skiver paprika & 0,7 \\
& 5 skiver agurk & 0,2 \\
& 1 glass lettmelk & 0 \\
& & \\
Middag & 1 porsjon helstekt landkylling, ovnsstekt & 0 \\
& 1 porsjon kokt fullkornsris & 1,0 \\
& 1 dl saus, av pulver & 0,2 \\
& 2 dl blandet salat med salatblad & 0,5 \\
& 1 stk. tomat & 1,4 \\
& 2 spiseskjeer kidneybønner (røde, hermetiske) & 3,5 \\
& 2 stk. knekkebrød, (type Wasa Husman eller Sport) & 4,6 \\
Kveldsmat & Med 4 skiver gulost & 0 \\
& 3 skiver paprika & 0,7 \\
& & \\
& 1 stk. eple & 3,1 \\
Totalt & 1 stk. pære & 5,0 \\
& 30 gram valnøtter & 1,4 \\
\hline & & $35 \mathbf{g}$ \\
\hline
\end{tabular}

Dagsmenyen er beregnet med Kostholdsplanleggeren, et gratis nettbasert næringsberegningsprogram (10). 


\section{Insulindosering bør tilpasses karbohydratinntaket ved diabetes type 1}

Personer med diabetes type 1 setter vanligvis hurtigvirkende insulin til måltidene for å erstatte manglende insulinproduksjon. Behandling med hurtigvirkende insulin gir en mye st $\varnothing$ rre fleksibilitet i hva og hvor mye den som har diabetes, kan spise, sammenliknet med ikke å bruke hurtigvirkende insulin til måltidene.

Både i Norge og Europa er det vanlig å dosere måltidsinsulin ut fra karbohydratinnholdet i måltidet, populært kalt karbohydratvurdering eller karbohydrattelling. Prinsippet går ut på at man estimerer innholdet av karbohydrater i det måltidet man ønsker å spise. Deretter doserer man måltidsinsulin på bakgrunn av denne estimeringen fordi karbohydrater i et måltid er det som $\varnothing$ ker blodsukkeret og dermed behovet for insulin.

I tillegg tilpasser man insulindosen ved å ta litt mer hvis blodsukkeret er høyt før måltidet, og litt mindre hvis man skal være fysisk aktiv før eller etter måltidet.

I både de norske retningslinjene og DNSGs utkast til anbefalinger foreslås det at alle som behandles med hurtigvirkende insulin, får grundig veiledning om hvordan de kan dosere måltidsinsulin ut fra måltidets innhold og sammensetning.

Karbohydratvurdering har i flere studier vist seg å være nyttig til slik bruk, men ga ikke bedre effekt på HbAic når denne metoden ble sammenliknet med annen diabetesrelatert kostveiledning i en kunnskapsoppsummering fra 2016 (11). Uansett tilnærming er det viktig at slik veiledning gis av helsepersonell med spesialkompetanse på diabetes og ernæring.

\section{Fett- og proteininntak er også viktig ved diabetes}

Selv om fett og proteiner har liten direkte effekt på blodsukkeret, er det ikke uvesentlig hvor mye og hvilken type fett og proteiner kostholdet inneholder. DNSG anbefaler at fett $\mathrm{i}$ kostholdet hovedsakelig skal komme fra plantebasert mat som har et høyt innhold av både enumettet og flerumettet fett.

Det vil si matvarer som nøtter, frø og planteoljer, bortsett fra palmeolje og kokosolje. Det er disse matvarene som bør erstatte mettet fett i kostholdet, da mettet fett ikke bør utgjøre mer enn 10 prosent av kaloriinntaket (12).

Det vil si et bytte fra fete meieri- og kjøttprodukter til magrere produkter eller produkter med umettet fett som plantemargariner, rapsolje, olivenolje andre planteoljer samt et høyere inntak av fisk, frø og nøtter. Kostens totale energiinnhold som kommer fra karbohydrat, fett og protein, benevnes ofte som energiprosent eller E\%. 
En slik kostendring vil ha positiv effekt på blodlipidene, altså totalkolesterol, LDL, HDL og triglyserider, og dermed også kunne forebygge hjerte- og karsykdom.

Dessuten har studier av personer både med og uten diabetes vist ytterligere positive effekter på HbA1c, insulinfølsomhet og fettlevernivå når deltakerne har byttet mettet fett med umettet fett i kostholdet (12).

Det finnes få gode studier på effekten av ulike typer og mengder protein i kosten hos personer med diabetes. En grundig gjennomgang av tilgjengelig litteratur har endt med at DNSG anbefaler omtrent det samme som tidligere (13): et proteininntak mellom 10 og 20 prosent av kaloriinntaket. Hos eldre bør det ligge nærmere 20 prosent av energiinntaket.

Derimot anbefaler vi at personer med diabetes og moderat nyresvikt bør ligge i det lavere området på grunn av $\varnothing k t$ belastning på nyrene ved høyt proteininntak. Dette tilsvarer cirka o,8 og 0,9 g/kg kroppsvekt hos henholdsvis kvinner og menn.

Nyrefunksjon måles ved å bestemme glomerulær filtrasjonsrate (GFR).

\section{Glomerulær filtrasjon}

«Glomerulær filtrasjon er transport av ultrafiltrat av plasma gjennom den glomerulære filtrasjonsbarrieren som består av kapillærveggen (endotel og basalmembran) og epitelceller, det første trinnet i produksjonen av urin.»

Kilde: Store medisinske leksikon

Nøyaktig måling av GFR er omstendelig og derfor måles heller konsentrasjonen av kreatinin i urinen, da kreatinin produseres med konstant rate, filtreres fritt over glomerulusmembranen og i liten grad absorberes eller sekreres i nyretubuli.

For å gjøre tolkningen av kreatininverdier lettere er det laget ulike formler der man estimerer GFR (estimert GFR; eGFR) for ulike kreatininverdier hos pasienter med ulik alder og kjønn (tabell 2) (14). Det finnes flere ulike formler for å beregne eGFR basert på kreatininkonsentrasjonen. 
Tabell 2. Gradering av og mål for hvordan nyrene fungerer

\begin{tabular}{|c|c|c|}
\hline GFR-kategori & Nyrefunksjon & $\begin{array}{l}\text { Glomerulær filtrasjonshastighet (ml/min/1,73 } \mathrm{m}^{2} \text { ) } \\
\text { (vanligvis brukes estimert GFR, eGFR) }\end{array}$ \\
\hline G1 & Normal & $\geq 90$ \\
\hline G2 & Lett redusert* & $60-89$ \\
\hline G3a & Lett til moderat redusert & $45-59$ \\
\hline G3b & Moderat til betydelig redusert & $30-44$ \\
\hline G4 & Betydelig redusert & $15-29$ \\
\hline G5 & Terminal nyresvikt & $<15$ \\
\hline \multicolumn{3}{|c|}{$\begin{array}{l}\text { * Hos eldre reduseres nyrefunksjonen årlig med } 0,5-1 \mathrm{ml} / \mathrm{min} / 1,73 \mathrm{~m}^{2} \text {. eGFR i området } 60-89 \mathrm{ml} / \mathrm{min} / 1,73 \mathrm{~m}^{2} \text { anses } \\
\text { normalt for eldre mennesker. }\end{array}$} \\
\hline \multicolumn{3}{|c|}{ Kilde: Helsedirektoratet (14) } \\
\hline
\end{tabular}

Et noe høyere proteininntak, opp mot 32 energiprosent, kan brukes kortvarig som en vektreduksjonsstrategi hos overvektige personer med diabetes type 2 og normal nyrefunksjon, der eGFR > 60 (13). Vektreduksjon har, som tidligere nevnt, positiv effekt på alle metabolske risikofaktorer ved diabetes og bedrer dessuten nyrefunksjonen.

\section{Plantebaserte kostmønstre er best ved diabetes}

Vi spiser jo ikke næringsstoffer, men matvarer og måltider som inneholder både fett, proteiner og karbohydrater i tillegg til ulike vitaminer, mineraler og andre mikronæringsstoffer. For at kostanbefalingene skal være praktiske å gjennomføre, har vi i de norske anbefalingene «oversatt» hva næringsstoffanbefalingene betyr, til konkrete kostråd (15).

DNSG har også nedlagt mye arbeid med å gjennomgå kunnskapsgrunnlaget for effekten ulike kostmønstre har på helsen til personer med diabetes. De har gjort en rekke kunnskapsoppsummeringer på blant annet middelhavskosthold (16), vegetarkost (17) og nordisk kost (ikke publisert enda).

Dette arbeidet er ikke ferdig, men fellestrekkene for kostmønstre som er gunstige ved diabetes, er at de inneholder mye nøtter, belgvekster som bønner, erter og linser, frukt, grønnsaker, fullkorn og/eller umettede planteoljer. Samtidig er innholdet av kjøtt, sukker og hvitt mel lavt. Disse kostmønstrene bedrer blodsukkerkontrollen og andre kardiometabolske risikofaktorer samt forebygger hjerte- og karsykdom.

\section{Diabetes type 2 kan forebygges}


Studier har vist at det er mulig å forebygge diabetes med intensiv livsstilsintervensjon: I to studier fra Finland (18) og USA (19) viste de at livsstilsintervensjon med oppmerksomhet på vektreduksjon gjennom sunt kosthold og $\varnothing \mathrm{kt}$ fysisk aktivitet kunne redusere antallet nye tilfeller av type 2-diabetes med 58 prosent hos personer med $\varnothing k t$ risiko for å utvikle sykdommen.

Livsstilsintervensjon for å forebygge diabetes type 2 ble allerede anbefalt i DNSGs kostanbefalinger fra 2004. Nå har vi imidlertid mange flere studier og dessuten langtidsresultater fra de første studiene som lå til grunn for de tidligere anbefalingene. Langtidsanalysene viser at effekten av intervensjonen fortsatt er tydelig 10 til 20 år etter at studien startet, og lenge etter at livsstilsendringsprogrammet ble avsluttet (20).

I sin kunnskapsoppsummering konkluderer derfor DNSG med at diabetes type 2 kan forebygges ved livsstilsendringer (20). Livsstilsendringer betyr her vektreduksjon ved hjelp av kostendringer i retning av gjeldende kostanbefalinger og mer fysisk aktivitet. Risikoreduksjonen har en klar sammenheng med vektreduksjon og hvorvidt deltakerne greide å holde på sin nye livsstil.

Det trengs flere studier for å finne ut hva som er den optimale kostsammensetningen i et kosthold som skal forebygge diabetes type 2. Studiene som har vist en god forebyggende effekt, har brukt en kosttype som er moderat i fettinnhold, lav på mettet fett, rik på fiber, fullkorn, frukt og grønnsaker eller er et middelhavskosthold.

\section{Hva er veien videre?}

Planen er at DNSG skal lansere sine kostanbefalinger ved diabetes i sin helhet på gruppens årlige møte, som finner sted 16.-19. juni 2022 i Aten (1). Dette er det 39. internasjonale symposiet om diabetes og ernæring som gruppen arrangerer, og den viktigste konferansen for oss som jobber og forsker på feltet diabetes og ernæring.

Når retningslinjen er lansert, er den neste store utfordringen for oss som jobber med dette, å innføre anbefalingene i våre respektive land. Dette arbeidet innebærer å omsette anbefalingene til praktiske og bærekraftige kostråd tilpasset regionale forskjeller i matkultur, tilgjengelighet og ernæringspolitikk.

For at retningslinjearbeidet skal ha noen mening, er det likevel avgjørende at personer med diabetes eller prediabetes får kunnskap om kostrådene, forstår og aksepterer dem og greier å innarbeide dem i sin egen hverdag og livsstil. 


\section{Referanser}

1. Diabetes and Nutrition Study Group (DNSG) of the European Association of Diabetes (EASD). Home. DNSG EASD; u.å. Tilgjengelig fra: https://dnsg-easd.eu/ (nedlastet 13.12.2021).

2. Churuangsuk C, Hall J, Reynolds A, Griffin SJ, Combet E, Lean MEJ. Diets for weight management in adults with type 2 diabetes: an umbrella review of published meta-analyses and systematic review of trials of diets for diabetes remission. Diabetologia. 2022;65(1):14-36. DOI: 10.1007/s00125-021-05577-2.

3. Lean ME, Leslie WS, Barnes AC, Brosnahan N, Thom G, McCombie L, et al. Primary care-led weight management for remission of type 2 diabetes (DiRECT): an open-label, cluster-randomised trial. Lancet. 2018;391(10120):541-51. DOI: 10.1016/So140-6736(17):33102-1

4. Lean MEJ, Leslie WS, Barnes AC, Brosnahan N, Thom G, McCombie L, et al. Durability of a primary care-led weight-management intervention for remission of type 2 diabetes: 2-year results of the DiRECT open-label, cluster-randomised trial. Lancet Diabetes Endocrinol. 2019;7(5):344-55. DOI: 10.1016/S2213-8587(19)30068-3

5. Korsmo-Haugen HK, Brurberg KG, Mann J, Aas AM. Carbohydrate quantity in the dietary management of type 2 diabetes: a systematic review and metaanalysis. Diabetes Obes Metab. 2019;21(1):15-27. DOI: 10.1111/dom.13499

6. Seidelmann SB, Claggett B, Cheng S, Henglin M, Shah A, Steffen LM, et al. Dietary carbohydrate intake and mortality: a prospective cohort study and metaanalysis. Lancet Public Health. 2018;3(9):e419-28. DOI: 10.1016/S2468$\underline{2667(18) 30135-\mathrm{X}}$

7. Reynolds AN, Akerman AP, Mann J. Dietary fibre and whole grains in diabetes management: systematic review and meta-analyses. PLoS Med. 2020;17(3):e1003053. DOI: 10.1371/journal.pmed.1003053

8. Helsedirektoratet. Utviklingen i norsk kosthold 2021. Oslo: Helsedirektoratet; 2021. Rapport. Tilgjengelig fra:

https://www.helsedirektoratet.no/rapporter/utviklingen-i-norsk-kosthold (nedlastet 10.12.2021).

9. Birkeland E, Gharagozlian S, Birkeland KI, Valeur J, Måge I, Rud I, et al. Prebiotic effect of inulin-type fructans on faecal microbiota and short-chain fatty acids in type 2 diabetes: a randomised controlled trial. Eur J Nutr. 2020;59(7):332538. DOI: $10.1007 / \mathrm{s} 00394-020-02282-5$ 
10. Mattilsynet, Helsedirektoratet. Kostholdsplanleggeren. Oslo: Mattilsynet, Helsedirektoratet, u.å. Tilgjengelig fra: https://www.kostholdsplanleggeren.no/ (nedlastet 17.12.2021).

11. Fu S, Li L, Deng S, Zan L, Liu Z. Effectiveness of advanced carbohydrate counting in type 1 diabetes mellitus: a systematic review and meta-analysis. Sci Rep. 2016;6:37067. DOI: 0.1038/srep37067

12. Schwab U, Reynolds AN, Sallinen T, Rivellese AA, Risérus U. Dietary fat intakes and cardiovascular disease risk in adults with type 2 diabetes: a systematic review and meta-analysis. Eur J Nutr. 2021;60(6):3355-63. DOI: 10.1007/s00394-021$\underline{\text { O2507-1 }}$

13. Pfeiffer AFH, Pedersen E, Schwab U, Risérus U, Aas A-M, Uusitupa M, et al. The effects of different quantities and qualities of protein intake in people with diabetes mellitus. Nutrients. 2020;12(2):365. DOI: 10.3390/nu12020365

14. Helsedirektoratet. Nyresykdom ved diabetes. Oslo: Helsedirektoratet; 2019. Tilgjengelig fra:

https://www.helsedirektoratet.no/retningslinjer/diabetes/nyresykdom-ved-diabetes (nedlastet 13.12.2021).

15. Helsedirektoratet. Levevaner ved diabetes og behandling av overvekt og fedme. Oslo: Helsedirektoratet; 2019. Tilgjengelig fra:

https://www.helsedirektoratet.no/retningslinjer/diabetes/levevaner-ved-diabetesog-behandling-av-overvekt-og-fedme\#kosthold-og-kostsam (nedlastet 13.12.2021).

16. Becerra-Tomás N, Mejía SB, Viguiliouk E, Khan T, Kendall CWC, Kahleova $\mathrm{H}$, et al. Mediterranean diet, cardiovascular disease and mortality in diabetes: a systematic review and meta-analysis of prospective cohort studies and randomized clinical trials. Crit Rev Food Sci Nutr. 2020;60(7):1207-27. DOI:

$\underline{10.1080 / 10408398.2019 .1565281}$

17. Viguiliouk E, Kendall CW, Kahleova H, Rahelic D, Salas-Salvado J, Choo VL, et al. Effect of vegetarian dietary patterns on cardiometabolic risk factors in diabetes: a systematic review and meta-analysis of randomized controlled trials. Clin Nutr. 2019;38(3):1133-1145. DOI: 10.1016/j.clnu.2018.05.032

18. Tuomilehto J, Lindstrom J, Eriksson JG, Valle TT, Hamalainen H, IlanneParikka P, et al. Prevention of type 2 diabetes mellitus by changes in lifestyle among subjects with impaired glucose tolerance. N Engl J Med. 2001;344(18):1343-50. DOI: $\underline{10.1056 / \mathrm{NEJM} 200105033441801}$ 
19. Knowler WC, Barrett-Connor E, Fowler SE, Hamman RF, Lachin JM, Walker $\mathrm{EA}$, et al. Reduction in the incidence of type 2 diabetes with lifestyle intervention or metformin. N Engl J Med. 2002;346(6):393-403. DOI: 10.1056/NEJMoao12512

20. Uusitupa M, Khan TA, Viguiliouk E, Kahleova H, Rivellese AA, Hermansen $\mathrm{K}$, et al. Prevention of type 2 diabetes by lifestyle changes: a systematic review and meta-analysis. Nutrients. 2019;11(11):2611. DOI: 10.3390/nu11112611 